\title{
A Novel Proteomic Approach Identifies New Interaction Partners for Proliferating Cell Nuclear Antigen
}

\author{
Laurence Meslet-Cladiere ${ }^{1, x^{*}}$, Cedric Norais ${ }^{1, x_{1}{ }^{*}}$, Joëlle Kuhn ${ }^{1}$, Julien Briffotaux ${ }^{2}$, Jerry W. \\ Sloostra $^{3}$, Elena Ferrari ${ }^{4}$, Ulrich Hübscher ${ }^{4}$, Didier Flament ${ }^{2^{\star}}$ and Hannu Myllykallio ${ }^{1^{*}}$
}

\author{
1 INSERM Avenir Group - Institut du Génétique et Microbiologie, CNRS UMR8621, U.Paris-Sud, 91405 Orsay \\ Cedex, France \\ 2 UMR 6197, Laboratoire de Microbiologie des Environnements Extrêmes, IFREMER Brest, 29280 Plouzane, \\ France \\ 3 Pepscan Systems, 8219 PH Lelystad, The Netherlands \\ 4Institute of Veterinary Biochemistry and Molecular Biology, University of Zurich-Irchel, Winterthurerstrasse 190, \\ $\mathrm{CH} 8057$ Zurich, Switzerland.
}

*Correspondence regarding SPR measurements should be addressed to D.F (didier.flament@ifremer.fr). All other correspondence should be addressed to H.M (hannu.myllykallio@igmors.u-psud.fr).xTwo first authors contributed equally in this work.

\begin{abstract}
:
During DNA replication and repair, many proteins bind to and dissociate in a highly specific and ordered manner from proliferating cell nuclear antigen (PCNA). We describe a combined approach of in silico searches at the genome level and combinatorial peptide synthesis to investigate the binding properties of hundreds of short PCNA-interacting peptides (PIP-peptides) to archaeal and eukaryal PCNAs. Biological relevance of our combined approach was demonstrated by identification an inactive complex of Pyrococcus abyssi ribonuclease HII with PCNA. Furthermore we show that PIP-peptides interact with PCNA largely in a sequence independent manner. Our experimental approach also identified many so far unidentified PCNA interacting peptides in a number of human proteins.
\end{abstract}

Keywords: PCNA; combinatorial peptide synthesis; ribonuclease HII

Abbreviations: PCNA, proliferating cell nuclear antigen; PIP-peptide, PCNA-interacting peptide; SPR, surface plasmon resonance 
Proliferating cell nuclear antigen (replication clamp PCNA) was originally identified as an antigen present in the nuclei of dividing cells that reacted with an autoantibody in the sera of patients with lupus erythematosus ${ }^{1}$. Later studies demonstrated that PCNA is a trimeric processivity factor of eukaryotic replicative DNA polymerases ${ }^{2}$. The outer surface of the ringshaped PCNA trimer is negatively charged whereas the central cavity accommodating DNA carries positive charges ${ }^{3}$. One PCNA monomer is composed of two domains that are linked by a domain-connecting loop. This loop is evolutionary conserved and plays a crucial role in mediating specific interactions of the replication clamp with its interaction partners in Okazaki fragment processing, DNA repair, translesion DNA synthesis, DNA methylation, chromatin remodeling and cell cycle regulation ${ }^{4}$. In order to be functionally active, different PCNAinteracting proteins must bind and dissociate in a highly specific and ordered manner. In view of this fact it is surprising that the identified peptide domain motifs of PCNA-interacting proteins (PIP-motifs) are quite similar and have overlapping binding sites with PCNA. For instance, the sequence motif $\mathrm{Q}-\mathrm{x}(2)-(\mathrm{h})-\mathrm{x}(2)-(\mathrm{a})-(\mathrm{a})$ (h, moderately hydrophobic residue; $\mathrm{a}, \mathrm{a}$ highly hydrophobic residue) is known to mediate interactions of archaeal and human PCNA with many partners ${ }^{5 ; 6}$. As these motifs are short, poorly conserved and can be found in literally thousands of proteins, the possibilities to identify (new) PCNA interacting proteins based solely upon in silico sequence comparisons are limited, making functional screens necessary. In this work we describe a combinatorial approach of in silico searches and combinatorial peptide synthesis to identify new PCNA interaction partners. In contrast to earlier screens that have used completely random peptide libraries, we have tested focused peptide libraries that were designed benefiting either from $P$. abyssi or human genome. As model for the proof of principle we used the presumed enzymatic machinery for the processing of Okazaki fragments in the hyperthermophilic archaeon Pyrococcus abyssi (P. abyssi). Our approach led to 
identification of new interaction partners for archaeal PCNA and allows predicting hitherto unidentified interaction partners for human PCNA. Biological significance of our results was revealed through identification of an inactive complex of $P$. abyssi ribonuclease (RNase) HII with PCNA, indicating also a DNA repair function for RNase HII orthologs. We also show that the PIP-motif sustains a considerable amount of substitutions without having deleterious effect on the PCNA binding. 


\section{Results and Discussion}

\section{Screening of immobilized peptides with the robust archaeal $P$. abyssi PCNA}

In order to experimentally identify PCNA-interacting peptides, we firstly screened a small library of 910 random $\mathrm{X}-\mathrm{C}-\mathrm{X}(8)-\mathrm{C}-\mathrm{X}$ peptides, immobilized onto a solid support via cysteine residues, with $2 \mu \mathrm{M}$ of stable PCNA preparation from $P$. abyssi. $P$. abyssi PCNA carries a six histidine tag at the amino terminal end, allowing detection of the bound protein by a specific anti-His antibody. The background signal resulting from non-specific binding of $P$. abyssi PCNA corresponded to binding values smaller than 100 arbitrary units; no signal was observed when PCNA was omitted from the binding reaction. These analyses allowed the identification of 47 immobilized lead peptides with binding values higher than five hundred for P. abyssi PCNA (Figure 1A and Table S1). Manual alignment showed that some of these peptides (Figure 1B) possess the PIP-motif ${ }^{6 ;}$. However, many additional peptides with high binding values did not show obvious sequence similarity to the PCNA-interacting protein motif (see Table S1), suggesting that physico-chemical or structural properties of these peptides played an important role in binding. This idea was supported by the fact that the average predicted isoelectric point (pI) of 50 high affinity peptides was statistically significantly higher than the pI of non-interacting peptides (8.46 versus 6.31, see Figure 1A). This observation indicates that the positive charge of these peptides could contribute to the observed binding. It is of note that previously performed peptide screens to identify new PCNA-binding peptides failed to identify statistically significant correlation between the PCNA binding and positive charge ${ }^{8 ; 9}$. This likely reflects the fact that not enough PCNA binding peptides were identified in earlier peptide screens and/or that binding values were not recorded for peptides with low affinities towards PCNA.

We next synthesized several control peptides found in $P$. abyssi proteins (Figure 1C) that were immobilized on a solid support and screened as above with $1 \mu \mathrm{M} P$. abyssi PCNA. 
Naturally occurring peptides with the highest binding values contained the conserved P. abyssi sequence motif Q-x(2)-L-x(2)-[WFT]-[LFT] (Figure 1C). We furthermore noted that this sequence motif is often flanked by positively charged residues (Figure 1C). Many "high affinity" peptides are present in proteins that are known to interact with the PCNA. However, we also found that peptides from P. abyssi ribonuclease H (RNase HII) and PAB2263, two proteins that previously have not been shown to interact with PCNA, contain a PIP-motif with a strong PCNA binding activity (Figure 1C).

\section{The interaction domains of $P$. abyssi RNase HII, flap endonuclease 1 and DNA ligase with PCNA overlap}

As a proof of principle, we next set out to further investigate how the above peptides when contained in archaeal proteins (their natural context) mediate interactions with PCNA. We studied the PCNA binding of the P. abyssi RNase HII, the structure-specific flap endonuclease 1 (Fen1) and the ATP-dependent DNA ligase using surface plasmon resonance (SPR). PCNA-interacting peptides located at the carboxyl termini of RNase HII and Fen1 have high binding values (Figure 1C), whereas the motif that was identified at the N-terminus of DNA ligase shows moderate affinity for PCNA. In this respect it is noteworthy that very recently an additional PIP-motif "QKSFF" in the central region of $P$. furiosus DNA ligase has been described ${ }^{10}$, suggesting that the two motifs could participate in efficient binding. First, recombinant proteins for SPR measurements, carrying a six histidine tag at the N-terminus, were produced and purified to greater than $99 \%$ homogeneity using Ni-NTA agarose and gel filtration chromatography (Figure 2A). SPR measurements with immobilized homotrimeric PCNA were performed to analyze the physical interactions of the purified proteins with PCNA (Figures 2B-D). The results indicated that RNase HII, Fen1 and DNA ligase physically interact with $P$. abyssi PCNA at nanomolar concentrations (Figure $2 \mathrm{~B}-\mathrm{D}$, trace 1 ). It is also of note that the high binding values observed for the individual peptides (Figure 1C and data not shown) 
correlate with the $\mathrm{K}_{\mathrm{D}}$ values in nanomolar range. These values were estimated using global fitting analysis that accounts for both association and dissociation phases as well as the maximal level of complex formation. It is interesting to note that the similar SPR data has been obtained for a PAB2263-PCNA complex of unknown function (manuscript in preparation).

To exclude that the observed SPR data result from the oligomerisation of the proteins studied and/or from non-specific interactions under the experimental conditions used, we performed deletion analyses and competition experiments. RNase HII, with a 17 residue deletion at the C-terminus that removed the PIP motif, failed to interact with PCNA (Figure 2B, insert). The competition experiments were performed in the presence of a ten-fold excess of the peptide KRKQLTLDNFLKR (bold residues correspond to conserved PIP motif residues). This peptide is a rationally designed composite peptide based on the RNase HII PIPpeptide (KRAQLTLDNFLK) where the alanine at the position 3 was changed to lysine that occurs in Fen1 and PAB2263 PIP-peptides in the corresponding positions. The binding value of this peptide is similar to those of Fen1 and PAB2263 (data not shown). The addition of this peptide substantially decreased the rate of complex formation and/or accelerated dissociation of RNase HII-, Fen1- and DNA ligase-PCNA complexes (Figure 2B-D, trace 3), whereas the nonbinding control peptide (KEVKEEYKRFLEE) had no effect on complex formation (Figure 2B$\mathrm{D}$, trace 2). These results clearly indicated that the binding sites for all three proteins with PCNA do considerably overlap. To obtain further evidence for the physiological significance of the interactions detected in vitro between PCNA, RNase HII and Fen1, their complex formation in cell free extracts was analyzed (Figure 2E). Fen1 and RNase HII were precipitated together with PCNA from cell-free extracts, whereas the lack of detectable interaction between DNA ligase and PCNA could be explained by additional PCNA interaction partners, present in cell-free extracts, preventing the binding of DNA ligase to PCNA. 
The specific physical interaction between $P$. abyssi PCNA and RNase HII measured by SPR suggested that PCNA might modulate the activity of RNase HII. We therefore examined the influence of PCNA on the enzymatic properties of $P$. abyssi RNase HII on heteroduplex substrate carrying embedded ribonucleotides, which likely corresponds to the physiologically relevant RNase HII substrate ${ }^{11 ; 12}$. Upon addition of PCNA the RNase HII activity on this substrate was strongly inhibited (Figure $2 \mathrm{~F}$ ). To test whether this inhibition results from a physical inhibitory interaction with PCNA, RNase HII activity was measured by changing the molar PCNA/RNase HII ratio in the reaction mixtures. These studies were performed with both wild-type (WT) RNase HII and its C-terminal deletion ( $\Delta$ Cter) derivative incapable of interacting with PCNA (Figure 2B). The results obtained revealed that inhibition of the ribonuclease activity of RNase HII by PCNA was dependent on the PIP-motif located at the Cterminus of the enzyme (Figure 2F). This inhibition could be explained by the fact that the substrate-binding domain of Thermococcus kodakaraensis RNase HII is located in a carboxy-

terminus ${ }^{11}$. In control experiments we found that the PCNA preparation used was capable to activate $P$. abyssi Fen 1 and DNA ligase (data not shown), indicating that PCNA was fully functional and properly folded.

\section{Archaeal RNase $\mathrm{H}$ and Fen1 have a key role in DNA repair}

To further define the physiologically relevant activities of archaeal RNase HII and Fen1, we inactivated the structural genes for RNase HII and Fen1 (Figure 3). For this we chose the halophile, Haloferax volcanii, since the necessary genetic tools have not been developed for Pyrococcus species. It is of note that we were unable to obtain a $H$. volcanii strain carrying a deletion of the structural gene for PCNA, suggesting that this processivity factor is essential in 
this organism. While $P$. abyssi contains only one RNase H (family II encoded by $r n h B$ ), $H$. volcanii contains detectable orthologs for RNase HII and RNase HI [likely bacterial origin (encoded by $r n h A)]$. Mutant strains, lacking $f e n 1, r n h A, r n h B$, or different combinations of these, were constructed and confirmed as indicated in Materials and Methods section. On solid medium, the "wild type" and $\Delta r n h B \Delta r n h A$ strains grew similarly whereas the growth of $\Delta f e n l$ deletion strain was impaired. This visual observation was confirmed by measuring the doubling time for the parental and $\Delta r n h B \Delta r n h A$ of $131 \pm 6(\mathrm{n}=5)$ and 108 (average of two measurements) minutes whereas $\Delta f e n l$ strain had the doubling time of 189 minutes (average of two measurements). We also measured the incorporation rate of extracellular tritiated uracil into alkaline resistant form (DNA) using these different mutant strains (Table 2). These measurements suggested that archaeal Fen1 has a role in DNA replication, as earlier observed for Eukarya ${ }^{13}$. On the other hand, the in vivo role of RNase HII in DNA replication was not evident (Table 2). Considering that GC\% of $H$. volcanii genome is relatively high, we can not exclude a possibility that $H$. volcanii RnhA origin participates in the processing of R-loops that could be found at some replication origins in this species ${ }^{14 ; 15}$.

We also tested our deletion strains for possible differences regarding their sensitivity to UV radiation (Table 2, Figure 4). Our results revealed that the fenl deletion resulted in markedly enhanced UV sensitivity, indicating that archaeal Fen1 either participates in removal of photoproducts resulting from UV irradiation and/or indicate a role in DNA replication occurring downstream of unrepaired damage on lagging strand templates ${ }^{13 ; 16}$. Our results also indicated that both single RNase H mutant strains are moderately UV sensitive (Table 2), with an additive effect observed for the $\Delta r n h A \Delta r n h B$ strain (Table 2 and Figure 3D). Thus, substrate specificity of archaeal RNase HII orthologs, inhibition of RNase HII activity by PCNA (Figure 2) and genetic studies (Figure 3) propose that major physiological role of archaeal RNase HII is not to participate in DNA replication but rather, possibly together with 
Fen1 endonuclease ${ }^{12}$, in repair of ribonucleotides misincorporated into chromosomal DNA. As translesion bypass polymerases capable of ribonucleotide misincorporation are often found in archaeal species exposed to UV radiation, for instance in $H$. volcanii, the Sulfolobales, and Picrophilus species ${ }^{17}$, translesion synthesis through the UV damaged DNA, could be one mechanism that increases ribonucleotide misincorporation in chromosomal DNA.

\section{Predicted interaction partners of human PCNA}

The above experiments performed with archaeal proteins indicated that a combination of motif searches and screening with immobilized peptides can be used to identify new PCNA interacting partners. To expand this notion to different systems, we next synthesized 98 peptides carrying the $\mathrm{Q}-\mathrm{x}(4,5)-[\mathrm{HDF}]-[\mathrm{FY}]$ motif occurring in human proteins. These peptides were subsequently screened with human PCNA carrying a C-terminal hexahistidine tag ${ }^{7}$. Figure 4A shows that, despite all 98 peptides screened contained the aforementioned sequence motif, the observed binding values varied between 80 and 1400 (left $y$ axis). These experimental data are consistent with the earlier prediction that variable PIP-box sequences could result in a wide range of PCNA affinities ${ }^{18}$. The sliding average (in a window of 10 peptides) of the calculated pIs (Fig. 4A, right $y$ axis), clearly indicates that high affinity peptides tend to be positively charged. Figure S1A shows an alignment of the peptides with observed binding values higher than 400 . This list not only contains proteins known to interact with PCNA (bolded in Figure S1A), but also reveals several potential novel interaction partners for human PCNA. Obviously, more experiments are now required to address whether these proteins interact functionally and/or physically with human PCNA.

Since the interaction surface between the PCNA and its interaction partners is at least

partially formed by the beta zipper peptide backbone ${ }^{19 ; 20}$, formation of the complex interface could be largely independent of the protein sequence. To test this, we synthesized 60 different peptides where the bolded positions in the peptide KRKQLTLDNFLKR were systematically 
changed to all naturally occurring amino acids (Figure 4B) and performed a further functional screening. Our results revealed that not even the "fully conserved" glutamine residue is indispensable for binding in our experiments. On the other hand, the hydrophobic substitutions at the positions 7 and 10 were favored. These results indicate that the short PIP-motif sustains a high number of substitutions without having a drastic effect on the binding activity. These observations are in agreement with the notion that the beta zipper formation together with electrostatic and hydrophobic interactions, and not specific protein sequence, is important for binding. Similar results further indicating specific binding independent of peptide sequence

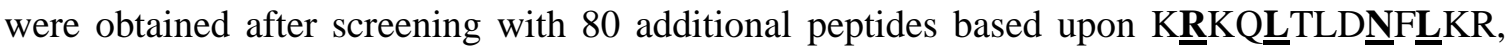
where the underlined residues were changed in the same way as above (Figure S1B). With these peptides we also performed a screening with the QLGI125 mutant in the domainconnecting loop of human PCNA. This loop participates in specific interactions of PCNA with its interaction partners, and the mutant PCNA has a markedly lower affinity towards Fen 1 than the wild type protein ${ }^{7}$. The signal observed with the QLGI125 mutant was consistently lower than observed for the wild type protein (Figure S1B), further indicating that the binding signal observed in our experiments is highly specific. The fact that binding by this mutant was not completely abolished in our experiments is in agreement with the proposed multi-factorial nature of this interaction.

\section{Conclusions}

We have developed an experimental approach that allows the rapid identification of peptide sequences with high affinity towards PCNA. Differently from the earlier peptide screens to identify PCNA binding peptides, we have benefited from the combined $P$. abyssi and human genome sequence information to synthesize a number of immobilized peptides carrying putative PIP-motifs. Usefulness and efficiency of this approach to identify novel PCNA 
interaction partners were revealed by our finding that $P$. abyssi PCNA and RNase HII form an inactive complex. While proof of principle was obtained using robust archaeal proteins, our data indicate that this experimental screening method can be extrapolated to human systems. In particular, we have identified new peptide sequences in human proteins with high affinity towards PCNA (Figure S1). Moreover, we can predict that some of the 233 positively charged peptides ( $\mathrm{pI}>$ 8.0) of human proteins carrying the modified PIP motif Q-X(2)-[LIMFV]-X(2)[DHFYW]-[FYAQ] are likely to correspond to additional candidate PCNA interaction partners (Figure 4C). Our results also indicate that the PIP-motif sustains a considerable amount of substitutions, indicating that PCNA binding of the PIP-peptides is mediated through beta zipper formation at the interaction surface ${ }^{19}$ and the positively charged residues (Figures 1 and 4). As this interaction is largely independent of the specific sequence, PCNA complexes are likely to persist even when the PIP-motif cannot be anymore recognized using computational approaches. Despite the power of genome comparison in the detection of linear interaction motifs being obvious ${ }^{21 ; 22}$, proteomics approaches like the one described here are clearly needed to validate the observed predictions. 


\section{Materials and Methods}

\section{Bacterial Strains}

Escherichia coli SURE [e14-(McrA-) $\Delta($ mcrCB-hsdSMR-mrr)171 endA1 supE44 thi-1 gyrA96

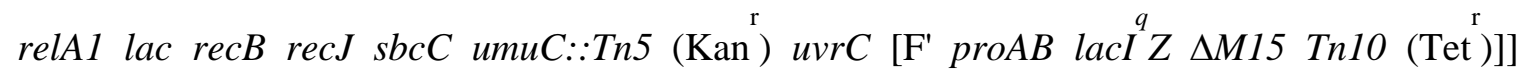
(Stratagene) was used as a host strain for maintaining plasmids. For protein expression, cisrepressed pQE-80L (Qiagen) derivatives were transformed into E. coli BL21 CodonPlus [E.

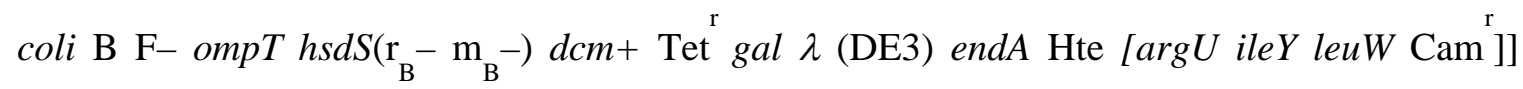
(Stratagene) containing extra copies for arginine, isoleucine and leucine tRNAs.

\section{Expression and purification of recombinant proteins}

Genes encoding P. abyssi PCNA (PAB1465), RNase HII (PAB0352), Fen1 (PAB1877) and DNA ligase (PAB2002) were amplified using 30 cycles of PCR with $\mathrm{CsCl}$ gradient purified chromosomal DNA as template (primer sequences will be made available upon request). pQE-80L (Qiagen) expression vector containing Isopropyl- $\beta$-D-thiogalactopyranoside (IPTG)-inducible bacteriophage T5 promoter was used to express all proteins. P. abyssi PCNA was cloned using BamHI and SalI restriction sites (all primer sequences are indicated in Table 2); all other proteins were cloned into BamHI and PstI sites of the pQE-80L expression vector. The resulting expression constructs encode full length proteins with a six-histidine tag at their amino-termini. A construct encoding truncated version of RNase HII lacking the 17 carboxyterminal residues and carrying PCNA interaction motif was produced in a similar manner.

Expression constructs were transformed into E. coli BL21-CodonPlus-RIL strain (Stratagene) using solid LB medium containing $100 \mu \mathrm{g} / \mathrm{mL}$ ampicillin. Protein expression was induced in exponential phase cultures by adding $0.5 \mathrm{mM}$ IPTG. After $2 \mathrm{~h}$ of induction, the cells were collected by centrifugation. Cell lysis was performed in buffer A (30 mM Hepes pH 8, $300 \mathrm{mM}$ 
$\mathrm{NaCl}$ ) with several freeze-thaw cycles, followed by brief sonication to decrease viscosity of supernatants. Cellular debris was eliminated by centrifugation. All chromatographic procedures were performed with an ÄKTA FPLC system at $10{ }^{\circ} \mathrm{C}$ (Amersham Biosciences). Tagged proteins were purified on immobilized Ni-NTA beads, according to the manufacturer's instructions (Qiagen), followed by purification on an S-200 gel filtration column (Amersham). All protein samples were analyzed for purity and integrity using 13\% SDS-polyacrylamide gel electrophoresis and by MALDI-TOF analyses (Innova Proteomics, France). Recombinant human wildtype PCNA as well as its QLGI125 mutant were purified to over 99\% homogeneity as previously described ${ }^{7 ; 23}$.

\section{Synthesis of peptides and Pepscan screening}

The overlapping synthetic peptides were synthesized and screened using credit-card format

mini-PEPSCAN cards (455-well-plate with $3 \mu$ l wells) as described previously ${ }^{24}$. The binding of antibodies to each peptide was tested in a PEPSCAN-based enzyme-linked immuno assay (ELISA). The 455-well creditcard-format polypropylene cards, containing the covalently linked peptides, were incubated with sample, for example $1 \mu \mathrm{g} / \mathrm{ml}$ PCNA diluted in a PBS solution which contains $5 \%$ horse-serum (v/v) and 5\% ovalbumin (w/v) and $1 \%$ Tween 80 $\left(4^{\circ} \mathrm{C}\right.$, overnight). After washing, the peptides were incubated with an anti-HIS tag antibody (dilution $1-1000$, Novagen $)\left(1 \mathrm{~h}, 25^{\circ} \mathrm{C}\right)$ and subsequently with a rabbit anti-mouse antibody peroxidase (dilution 1/1000, Dako) $\left(1 \mathrm{~h}, 25^{\circ} \mathrm{C}\right)$. After washing the peroxidase substrate, 2,2'azino-di-3-ethylbenzthiazoline sulfonate (ABTS) and $2 \mu \mathrm{l} / \mathrm{ml} 3 \% \mathrm{H}_{2} \mathrm{O}_{2}$ were added. After $1 \mathrm{~h}$ color development of the ELISA was quantified with a CCD-camera and an image processing system.

\section{Interaction studies}

Surface plasmon resonance studies were performed in a BIAcore $\mathrm{X}$ apparatus (BIAcore, Uppsala Sweden), the interactions were monitored at $25^{\circ} \mathrm{C}$ at a flow rate of $30 \mu \mathrm{l} / \mathrm{min}$ in $\mathrm{HBS}$ - 
P buffer (10 mM Hepes, pH 7.4; $150 \mathrm{mM} \mathrm{NaCl}$ and $0.005 \%$ (v/v) P20). PCNA was aminecoupled on the surface of CM5 sensor chips (BIAcore) in $10 \mathrm{mM}$ sodium acetate buffer, $\mathrm{pH}$ 4.5. The level of immobilisation of PCNA was of about 150 resonance units (RU).

P. abyssi GE5 (strain Orsay) cell free extracts were prepared from anaerobically grown 2 liter cultures using a gas-lift bioreactor, which was prepared as previously described ${ }^{25}$. Cell suspensions were harvested in exponential phase (approximately $2.0 \times 10^{8}$ cells $/ \mathrm{ml}$ ) and centrifuged at $5000 \mathrm{x}$ g for $45 \mathrm{~min}$. Cells were suspended in $50 \mathrm{mM}$ Tris- $\mathrm{HCl}, \mathrm{pH} 8 ; 0.5 \mathrm{mM}$ dithiothreitol, $150 \mathrm{mM} \mathrm{NaCl}$ and lysed by sonication using a Vibracell sonifier (15 pulses of 30 sec, $375 \mathrm{~W}, 40 \%$ amplitude). After centrifugation at $10000 \mathrm{x} \mathrm{g}$ for $15 \mathrm{~min}$, the supernatant was used as the cell free extract. $20 \mu \mathrm{g}$ of His-tagged recombinant proteins were incubated with 1.6 mg of $\mathrm{Co}^{2+}$ magnetic micro beads (Dynabeads® TALONTM, Dynal Biotech) in $1 \mathrm{ml}$ of binding and washing buffer (50 mM Na-phosphate, $\mathrm{pH} 8 ; 300 \mathrm{mM} \mathrm{NaCl}$ and $0.01 \%$ Tween 20) for 20 min at $25{ }^{\circ} \mathrm{C}$. Proteins bound to the beads were washed three times in the same buffer. The beads were then incubated with $12.5 \mathrm{mg}$ of whole-cell extract for $2 \mathrm{~h}$ at $4^{\circ} \mathrm{C}$. After five washing steps using the above mentioned buffer, proteins bound to the target proteins were eluted in $1 \mathrm{M}$ Tris, $\mathrm{pH} 8.8 ; 2 \%(\mathrm{w} / \mathrm{v}) \mathrm{SDS}, 5 \%(\mathrm{v} / \mathrm{v}) \beta$-mercaptoethanol, $8 \%(\mathrm{v} / \mathrm{v})$ sucrose and $0.1 \%(\mathrm{w} / \mathrm{v})$ bromophenol blue (SDS sample buffer). The eluted samples were separated in an SDS $12 \%$ polyacrylamide gel and transferred to a nitrocellulose membrane. After membranes were blocked with $5 \%$ milk in TBST buffer $(10 \mathrm{mM}$ Tris- $\mathrm{HCl}, \mathrm{pH} 7.5 ; 150 \mathrm{mM} \mathrm{NaCl}$ and 0.05\% (v/v) Tween 20), polyclonal anti-PCNA antibody (raised in rabbits by Eurogentec) was incubated for $1 \mathrm{~h}$ at $25^{\circ} \mathrm{C}$ and then washed in TBST. Immunocomplexes were detected using an enhanced chemiluminescence procedure according to the manufacturer's recommendations (Amersham). 


\section{RNase HII assays}

Activity assays using RNase HII were performed essentially as described ${ }^{26}$. A substrate consisting of oligonucleotides O8 and O9 (Table 1) was obtained by mixing a deoxyoligonucleotide carrying an embedded ribonucleotide in a 1:1 molar ratio with the complementary strand in $20 \mathrm{mM}$ Tris- $\mathrm{HCl}, \mathrm{pH} 8,0$ and $150 \mathrm{mM} \mathrm{NaCl}$, followed by an incubation at $75^{\circ} \mathrm{C}$ for $15 \mathrm{~min}$. After this incubation step, oligonucleotides were cooled slowly at room temperature and conserved at $-20^{\circ} \mathrm{C}$ until use.

Where indicated, one of oligonucleotides used in the hybridizations was labelled either on the 5'-end with $[\gamma-32 \mathrm{P}]$ ATP by using T4 Polynucleotide kinase (Promega) or, alternatively, the 3 '-end was marked using the Terminal Desoxynucleotide Transferase (Promega) and $[\alpha-32 \mathrm{P}]$ ddATP (Amersham). Free label was removed from oligonucleotide solutions using Sephacryl G25 MicroSpin columns (Amersham). Reaction products and substrates were separated under denaturing conditions. Polyacrylamide gels were dried on Whatman filter paper and reactions were quantified using Storm system.

\section{Gene deletion in Haloferax volcanii}

Gene deletion in H. volcanii strain $\mathrm{H} 53$ ( $\mathrm{pHV}^{-}$ApyrE2 $\triangle$ trpA) and segregation of mutant alleles were carried out using the optimized pop-in/pop-out system ${ }^{27 ;}{ }^{28}$. A non-selective enriched medium Hv-YPC or a selective Hv-Ca medium were used for cell growth. Where appropriate, selective medium was supplemented with uracil and tryptophane $(50 \mu \mathrm{g} / \mathrm{ml}$ each) or, alternatively, using a combination of 5-fluoroorotic acid $(50 \mu \mathrm{g} / \mathrm{ml})$ and uracil $(10 \mu \mathrm{g} / \mathrm{ml})$ with or without tryptophane $(50 \mu \mathrm{g} / \mathrm{ml})$. Plasmids used for $H$. volcanii gene inactivation carried approximately 500 bp 5' upstream and 3' downstream the ORF sequences (oligonucleotides used are indicated in Table 1). PCR analyses were used to confirm that the constructed strains corresponded to the expected deletion strains (Figure 3A-C). Flanking regions were amplified using PCR and cloned into pTA131 containing a pyrE2 selection marker using EcoRI and XbaI 
restriction sites, yielding plasmids pCN7 (carrying the $\Delta r n h B$ allele) and pCN6 $(\Delta f e n l)$. Noncompleted genome sequence of $H$. volcanii was used for primer design (www.tigr.org). $\operatorname{trpA}$ selection marker from pTA298 ${ }^{27}$ was inserted at the BamHI site of pHM306 (Apcna::trpA), pYGH40 ( $(r n h A:: \operatorname{trp} A)$ and pCN9 $(\Delta r n h B:: \operatorname{trp} A)$ that was created between two inserted fragments. The non-replicative plasmids obtained were reisolated from E. coli SCS110 [dam $/ \mathrm{dcm}^{-}$(Stratagene)] and non-methylated DNA was used to transform $H$. volcanii using polyethylene glycol 600 as described ${ }^{29}$.

\section{Computational methods}

Scan prosite (http://www.expasy.org/tools/scanprosite/) with variations of PIP-motifs was used to scan P. abyssi or Homo sapiens protein sequence(s) from Swiss-Prot and TrEMBL databases. For human proteins, description filter "DNA" was used to limit the number of the hits. The manipulation suite hosted at http://www.bioinformatics.vg/sms/protein_iep.html was used to predict isoelectric points for the different peptides. Statistical tests were performed using OriginPro 7.5 software package (OriginLab Corporation). 


\section{Acknowledgements:}

We thank G. Henneke for helpful discussions, P. van Dijken for comments on combinatorial peptide synthesis and U. Liebl for critical comments on the manuscript, We also thank INSERM U613 (Molecular Genetics and Genetic Epidemiology, Brest, France) for access to surface plasmon resonance facilities. Our work on archaeal and eukaryotic DNA replication is supported by European Union programs [REPBIOTECH (contract number QLK3-CT-200202071) and Marine Genomics (contract number: PNGOCE-CT-2004-505403)]. D.F also thanks French National Institute of Marine Genomics for financial support (contract number: FNS-

500-370). H. M. acknowledges INSERM AVENIR program and Fondation Bettencourt Schueller for financial support. U.H. and E.F. are supported by the University of Zürich. 


\section{References}

1. Miyachi, K., Fritzler, M. J. \& Tan, E. M. (1978). Autoantibody to a nuclear antigen in proliferating cells. J Immunol 121, 2228-34.

2. Prelich, G., Tan, C. K., Kostura, M., Mathews, M. B., So, A. G., Downey, K. M. \& Stillman, B. (1987). Functional identity of proliferating cell nuclear antigen and a DNA polymerase-delta auxiliary protein. Nature 326, 517-20.

3. Gulbis, J. M., Kelman, Z., Hurwitz, J., O'Donnell, M. \& Kuriyan, J. (1996). Structure of the C-terminal region of p21(WAF1/CIP1) complexed with human PCNA. Cell 87, 297-306.

4. Maga, G. \& Hubscher, U. (2003). Proliferating cell nuclear antigen (PCNA): a dancer with many partners. J Cell Sci 116, 3051-60.

5. Duggin, I. G. \& Bell, S. D. (2006). The chromosome replication machinery of the archaeon Sulfolobus solfataricus. J Biol Chem 281, 15029-32.

6. Warbrick, E. (1998). PCNA binding through a conserved motif. Bioessays 20, 195-9.

7. Jonsson, Z. O., Hindges, R. \& Hubscher, U. (1998). Regulation of DNA replication and repair proteins through interaction with the front side of proliferating cell nuclear antigen. Embo $J$ 17, 2412-25.

8. Xu, H., Zhang, P., Liu, L. \& Lee, M. Y. (2001). A novel PCNA-binding motif identified by the panning of a random peptide display library. Biochemistry 40, 451220.

9. Warbrick, E. (2006). A functional analysis of PCNA-binding peptides derived from protein sequence, interaction screening and rational design. Oncogene 25, 2850-9.

10. Kiyonari, S., Takayama, K., Nishida, H. \& Ishino, Y. (2006). Identification of a novel binding motif in pyrococcus furiosus DNA ligase for the functional interaction with proliferating cell nuclear antigen. J Biol Chem.

11. Haruki, M., Tsunaka, Y., Morikawa, M. \& Kanaya, S. (2002). Cleavage of a DNARNA-DNA/DNA chimeric substrate containing a single ribonucleotide at the DNARNA junction with prokaryotic RNases HII. FEBS Lett 531, 204-8.

12. Rydberg, B. \& Game, J. (2002). Excision of misincorporated ribonucleotides in DNA by RNase H (type 2) and FEN-1 in cell-free extracts. Proc Natl Acad Sci U S A 99, 16654-9.

13. Liu, Y., Kao, H.-I. \& Bambara, R. A. (2004). FLAP ENDONUCLEASE 1: A Central Component of DNA Metabolism. Annual Review of Biochemistry 73, 589-615.

14. Sandler, S. J. (2005). Requirements for replication restart proteins during constitutive stable DNA replication in Escherichia coli K-12. Genetics 169, 1799-806.

15. Yu, K., Roy, D., Huang, F. T. \& Lieber, M. R. (2006). Detection and structural analysis of R-loops. Methods Enzymol 409, 316-29.

16. Rossi, M. L., Purohit, V., Brandt, P. D. \& Bambara, R. A. (2006). Lagging strand replication proteins in genome stability and DNA repair. Chem Rev 106, 453-73.

17. Kelman, Z. \& White, M. F. (2005). Archaeal DNA replication and repair. Curr Opin Microbiol 8, 669-76.

18. Bruning, J. B. \& Shamoo, Y. (2004). Structural and thermodynamic analysis of human PCNA with peptides derived from DNA polymerase-delta p66 subunit and flap endonuclease-1. Structure 12, 2209-19.

19. Chapados, B. R., Hosfield, D. J., Han, S., Qiu, J., Yelent, B., Shen, B. \& Tainer, J. A. (2004). Structural basis for FEN-1 substrate specificity and PCNA-mediated activation in DNA replication and repair. Cell 116, 39-50.

20. Vijayakumar, S., Chapados, B. R., Schmidt, K. H., Kolodner, R. D., Tainer, J. A. \& Tomkinson, A. E. (2007). The C-terminal domain of yeast PCNA is required for 
physical and functional interactions with Cdc9 DNA ligase. Nucleic Acids Res 35, 1624-37.

21. Neduva, V. \& Russell, R. B. (2005). Linear motifs: evolutionary interaction switches. FEBS Lett 579, 3342-5.

22. Neduva, V. \& Russell, R. B. (2006). Peptides mediating interaction networks: new leads at last. Curr Opin Biotechnol 17, 465-71.

23. Schurtenberger, P., Egelhaaf, S. U., Hindges, R., Maga, G., Jonsson, Z. O., May, R. P., Glatter, O. \& Hubscher, U. (1998). The solution structure of functionally active human proliferating cell nuclear antigen determined by small-angle neutron scattering. $J \mathrm{Mol}$ Biol 275, 123-32.

24. Slootstra, J. W., Puijk, W. C., Ligtvoet, G. J., Langeveld, J. P. \& Meloen, R. H. (1996). Structural aspects of antibody-antigen interaction revealed through small random peptide libraries. Mol Divers 1, 87-96.

25. Sharp, R. J. \& Raven, N. D. H. (1997). Isolation and growth of hyperthermophiles. In Applied Microbial Physiology: A practical approach (Rhodes, P. M. \& Stanbury, P. F., eds.), pp. 23-51. IRL Press, Oxford University press.

26. Chapados, B. R., Chai, Q., Hosfield, D. J., Qiu, J., Shen, B. \& Tainer, J. A. (2001). Structural biochemistry of a type 2 RNase H: RNA primer recognition and removal during DNA replication. J Mol Biol 307, 541-56.

27. Allers, T., Ngo, H.-P., Mevarech, M. \& Lloyd, R. G. (2004). Development of Additional Selectable Markers for the Halophilic Archaeon Haloferax volcanii Based on the leuB and trpA Genes. Appl. Environ. Microbiol. 70, 943-953.

28. Bitan-Banin, G., Ortenberg, R. \& Mevarech, M. (2003). Development of a Gene Knockout System for the Halophilic Archaeon Haloferax volcanii by Use of the pyrE Gene. J. Bacteriol. 185, 772-778.

29. Cline, S. W., Schalkwyk, L. C. \& Doolittle, W. F. (1989). Transformation of the archaebacterium Halobacterium volcanii with genomic DNA. J Bacteriol 171, 4987-91.

30. Myllykallio, H., Lopez, P., Lopez-Garcia, P., Heilig, R., Saurin, W., Zivanovic, Y., Philippe, H. \& Forterre, P. (2000). Bacterial mode of replication with eukaryotic-like machinery in a hyperthermophilic archaeon. Science 288, 2212-5. 
Table 1: Oligonucleotides used in this study.

\begin{tabular}{|c|c|c|}
\hline Usage & Oligonucleotides & Sequence 5' to 3' \\
\hline \multicolumn{3}{|c|}{ Recombinant proteins: } \\
\hline \multirow{2}{*}{ PCNA } & PCNA Bglll & ccatagatctATGCCATTCGAGATAGTC \\
\hline & PCNA Sall & ccatgtccgagtcgacTTAСТССТСААСССТGGG \\
\hline \multirow{2}{*}{ Fen1 } & Fen1 BamHI & ccatggatccATGGGAGTTCCTATAGGGG \\
\hline & Fen1 Pstl & ccatctgcagTTAGGGTTTCTTTTTGATGAACCAGC \\
\hline \multirow{2}{*}{ RnaseHII } & Rnase HII BamHI & ccatggatccATGAAGGTTGCCGGAGCAGATG \\
\hline & Rnase HII Pstl & ccatctgcagTTAATTGCGAAACCGCTTAAG \\
\hline \multirow{2}{*}{ Ligase } & Lig1 BamHI & ccatggatccATGAGGTACATAGAGCTGGCC \\
\hline & Lig1 Pstl & ccatctgcagTTACACСТTTCССТTСАТССТС \\
\hline \multicolumn{3}{|c|}{ Gene deletion: } \\
\hline \multirow{4}{*}{$\begin{array}{c}\text { pcna } \\
\text { deletion }\end{array}$} & Hvo1 PCNA5 & gatcgaattcGTCGCGGGCGTCGCCGCGCCA \\
\hline & Hvo1 PCNA3 & gatcggatccATATGATGTTCGCACGCTCTC \\
\hline & Hvo2 PCNA5 & gatcggtccGAGCCGTCCCACTCGTTTCTC \\
\hline & Hvo2 PCNA3 & gatctctagaGGGTCGAAGTCGAGCGGGCCT \\
\hline \multirow{4}{*}{$\begin{array}{c}\text { fen1 } \\
\text { deletion }\end{array}$} & OCN39 & gctctagagCAGTTCGGCCATGGAGTTCG \\
\hline & OCN40 & cgggatcccgAGTGACCGGCGTCGATTTCG \\
\hline & OCN41 & cgggatcccGGCGCGCTCGCATCGAGACA \\
\hline & OCN42 & ggaattccAGCATTCCGTAGGTTGCCGAG \\
\hline \multirow{5}{*}{$\begin{array}{c}\text { fen1 } \\
\text { control }\end{array}$} & OCN72 & GTCGTAGACGGGTGCGAAG \\
\hline & OCN93 & GCGCGAAGGAGTTGAACC \\
\hline & OCN144 & GGTGTCGTTTGACGAGGTG \\
\hline & OCN145 & GAGCTGTCGGAGCGTGTAG \\
\hline & OCN92 & CGAACCAGCCCGTGTAAA \\
\hline \multirow{4}{*}{$\begin{array}{c}\text { rnhA } \\
\text { deletion }\end{array}$} & OCN138 & ggaattcCCTCCTTCCGACA \\
\hline & OCN141 & gctctagACTCGAGCGACTCCGGTAA \\
\hline & YGH19 & gtttatccacgggatccAGTTGGACCTCGACAACCTC \\
\hline & OCN140 & acgcacataacggatccAGAACTCCCCGAAGACGTG \\
\hline \multirow{5}{*}{$\begin{array}{c}\text { rnhA } \\
\text { control }\end{array}$} & YGH32 & GATTTCCTTGCGCTCGAC \\
\hline & YGH33 & CCGGTCTCCTCGTGAATC \\
\hline & OCN150 & CGGGAAAGTCGTCGTACAG \\
\hline & OCN151 & CCTCGTTGGCTAGGGAGTC \\
\hline & YGH34 & AGCACGTCTTCGGGGAGT \\
\hline \multirow{4}{*}{$\begin{array}{c}r n h B \\
\text { deletion }\end{array}$} & OCN43 & ccgctcgagCGACATGGTCGAGCGCGTG \\
\hline & OCN44 & cctcaagcttACCTGGTCGGGTCTTGGGGTG \\
\hline & OCN45 & gctcaagcttGGCGTCGGGGAACCGGCGG \\
\hline & OCN46 & cgcggatccCGGCCTCGACGATTCTCGAAG \\
\hline \multirow{5}{*}{$\begin{array}{c}\text { rnhB } \\
\text { control }\end{array}$} & OCN74 & CGTGGTCGAAATCATGGAG \\
\hline & OCN94 & ACCGCAACCTCTAATTTTCC \\
\hline & OCN152 & CGAGACGGACATGAACCTG \\
\hline & OCN153 & ACGTACTCCCGCAGGAACT \\
\hline & $\varepsilon \quad$ OCN95 & GTAATCGTCTCCGCGATTC \\
\hline \multicolumn{3}{|c|}{ RNase HII Substrate (Bold A refers to a ribonucleotide): } \\
\hline & $\mathrm{O} 8$ & CCGTCCCACCGTGCC \\
\hline & O9 & GGCACGGTGGGACGG \\
\hline
\end{tabular}


Table 2: Genotypes and phenotypes of various Haloferax volcanii strains.

\begin{tabular}{|c|c|c|c|}
\hline Name & Genotype & $\begin{array}{c}\text { Incorporation } \\
\text { rate }^{\mathbf{1}}\end{array}$ & $\begin{array}{c}\text { \% of survival } \\
\text { Ultraviolet light }^{\mathbf{2}} \\
\left.\mathbf{( 1 1 2} \mathbf{~ J / \mathbf { m } ^ { 2 }}\right)\end{array}$ \\
\hline H53 & Wild type $^{3}$ & $100 \%$ & 0.25 \\
\hline CN7 & $\Delta r n h B$ & $130 \%$ & 0.035 \\
\hline CN8 & $\Delta f e n 1$ & $70 \%$ & 0.000125 \\
\hline CN9 & $\Delta f e n 1 / \Delta r n h B$ & $65 \%$ & 0.0025 \\
\hline CN10 & $\Delta r n h A$ & $75 \%$ & 0.15 \\
\hline CN11 & $\Delta r n h A / \Delta r n h B$ & $108 \%$ & 0.005 \\
\hline CN16 & $\Delta f e n 1 / \Delta r n h A$ & $68 \%$ & 0.0003 \\
\hline CN17 & $\Delta f e n 1 /$ & $33 \%$ & 0.006 \\
\hline
\end{tabular}

\footnotetext{
${ }^{1}$ Relative incorporation rates of tritiated uracil (marked at the positions 5 and 6 of pyrimidine ring) into alkaline resistant form (chromosomal DNA) was measured during early exponential growth phase using TCA precipitation as described 30. Myllykallio, H., Lopez, P., Lopez-Garcia, P., Heilig, R., Saurin, W., Zivanovic, Y., Philippe, H. \& Forterre, P. (2000). Bacterial mode of replication with eukaryotic-like machinery in a hyperthermophilic archaeon. Science 288, 2212-5. $100 \%$ corresponds to incorporation of $0.5 \mathrm{fmol}$ of tritiated uracil into alkaline resistant form in one hour by the strain $\mathrm{H} 53$. Cell numbers were normalized using $\mathrm{OD}_{600}$ values prior all labelling experiments.

${ }^{2}$ Percentage of survival was measured using a $90 \mathrm{~s}$ exposure with a dose of $1.24 \mathrm{~J} / \mathrm{m}^{2} / \mathrm{s}$. Survival curves for H53, CN8 and CN11 strains are shown in Figure 3.

${ }^{3}$ Haloferax volcanii strain $\mathrm{H} 53$ is referred to as "wild type" through out this work.
} 


\section{Figure legends:}

Figure 1: Screening of immobilized peptides with the robust archaeal $P$. abyssi replication clamp. (A) Screening of 910 random peptides with P. abyssi PCNA. Binding is indicated in arbitrarily chosen fluorescence units. Peptides were sorted according to the observed binding values. Predicted pI values for 50 high "affinity" peptides were statistically higher than for 300 peptides with the lowest binding values. Synthetic peptides were synthesized and screened using credit-card format mini-PEPSCAN cards (455-well-plate with $3 \mu$ wells) as described in the Materials and Methods section. (B) Lead peptides isolated from a random library with high affinity for P. abyssi PCNA. Hydrophobic residues in the vicinity of the conserved glutamine (in blue) are indicated in bold and positively charged residues are shown in red. (C) Screening of candidate P. abyssi PCNA interacting peptides. Sequences were identified using ScanProsite in the proteins encoded by the $P$. abyssi genome sequence. Relative binding values in arbitrary units are indicated on the right. The concentration of $P$. abyssi PCNA used for binding studies was $1 \mu \mathrm{g} / \mathrm{ml}$. Several control negative control peptides with their binding values are shown at the bottom of Figure 1C. ND, not detected.

Figure 2: The interaction domains of $P$. abyssi RNase HII, Fen1 and DNA ligase with PCNA overlap (A) The proteins used in this study: $1 \mu \mathrm{g}$ of each purified $P$. abyssi or human DNA replication proteins were separated on a 13\% SDS-PAGE and stained by Coomassie blue. RNase HII $\Delta \mathrm{Ct}$ refers to the carboxy-terminal deletion derivative of $P$. abyssi RNase HII (see Material and methods). (B-D) Experiments on PCNA chips. Ten pmoles of RNase HII (B), Fen1 (C) or DNA ligase (D) were injected at time 0 over the PCNA chip (trace 1; panels B, C and D). All data are indicated in RU units as a function of time. When indicated, 100 pmoles of non-interacting peptide control (trace 2) or a control peptide KRKQLTLDNFLKR were included during injection (trace 3). As an additional control an interacting peptide alone over 
the PCNA chip was injected (trace 4). The background resulting from buffer injection was always subtracted. The insert in $\mathbf{B}$ shows that the C-terminal PIP-domain of the P. abyssi RNase HII is necessary and sufficient for binding to the PCNA chip. + Cter, wild type P. abyssi RNase HII; $\Delta$ Cter, $P$. abyssi RNase HII lacking 17 residues from the amino terminus. (E) $A$ pull down experiment on magnetic beads. $20 \mu \mathrm{g}$ of histidine-tagged Fen1, RNaseHII or DNA ligase (from left to right) bound to magnetic beads, and a negative control that consists of beads alone, were incubated with $12.5 \mathrm{mg}$ of $P$. abyssi cellular extract. Control lanes contained $7 \mu \mathrm{g}$ of cell free extract and $15 \mathrm{ng}$ of PCNA. Pull-down assay, SDS-polyacrylamide gel electrophoresis and immunoblot using anti-PCNA antibodies were performed as described in Material and Methods. (F) RNase H activities in dependence of PCNA. Activities of RNase HII and RNase HII $\Delta$ Cter (1 pmol) were tested on a DNA substrate radioactively labelled at 5'terminus containing a single embedded ribonucleotide ( 1 pmol per $20 \mu$ reaction) in the absence and the presence of $P$. abyssi PCNA.

Figure 3: Deletion of fen1, $r n h A$ and $r n h B$ genes in Haloferax volcanii. (A) Schematics indicating the annealing positions of the primers (arrows) used to confirm the deletions for each gene. Homology sequences used for the pop-in/pop-out constructs are shown by shaded boxes, the strait line corresponds to the chromosome and the undulated line to the remains of plasmidic DNA after the pop-out. (B) The expected sizes of the PCR products obtained with the different primer sets are shown for each deletion. Table also indicated genotypes for the strains used in this work (C): Agarose gel electrophoresis confirming gene deletions. The PCR products obtained using either the wild type H53 or the triple mutant CN17 DNA. Each product presents the expected size indicating the loss of fenl, $r n h A$ and $r n h B$ genes in the strain CN17. Similar results were obtained for the other strains indicated in Table 2. (D) Fraction of surviving $H$. volcanii cells on solid enriched media as a function of UV exposure is shown. One 
second exposure corresponds to $1.24 \mathrm{~J} / \mathrm{m}^{2}$. The strains used were $\mathrm{H} 53$ (wild type), CN11 $(\Delta r n h A \Delta r n h B)$, and $\mathrm{CN} 8(\Delta f e n 1)$.

Figure 4: Predicted interaction partners of human PCNA (A) Screening of 98 naturally occurring peptides present in human proteins annotated in Swiss-Prot database containing the sequence motif $x(3)-Q-x(4,5)-[H D F]-[Y F]-x(3)$. The screening was performed with human PCNA $(1 \mu \mathrm{g} / \mathrm{ml})$. The average pI value for 25 top binders was $8.40(\mathrm{n}=25)$ and for the nonbinders $5.87(\mathrm{n}=25)$. Two sample independent t-test revealed that the difference of population means was significantly different (p-value=0.00113) (B) Positional scan of the underlined residues in the peptide KRKQLTL $D N \underline{F} L K K$. These residues correspond to the conserved residues of the archaeal and eukaryal PIP-motif. Green columns correspond to "wild type" peptides whereas peptides carrying substitution are indicated in blue. Binding values where normalized using the values obtained for "wild type" peptide. (C) Frequency distribution of pI values for 779 human peptides with the predicted PIP-motif. Note that the data shown in Figures $1 \mathrm{C}$ and $3 \mathrm{~A}$ already provide experimental support suggesting that some positively charged peptides in this data set could be used to identify novel interaction partners for the human PCNA. 
A.

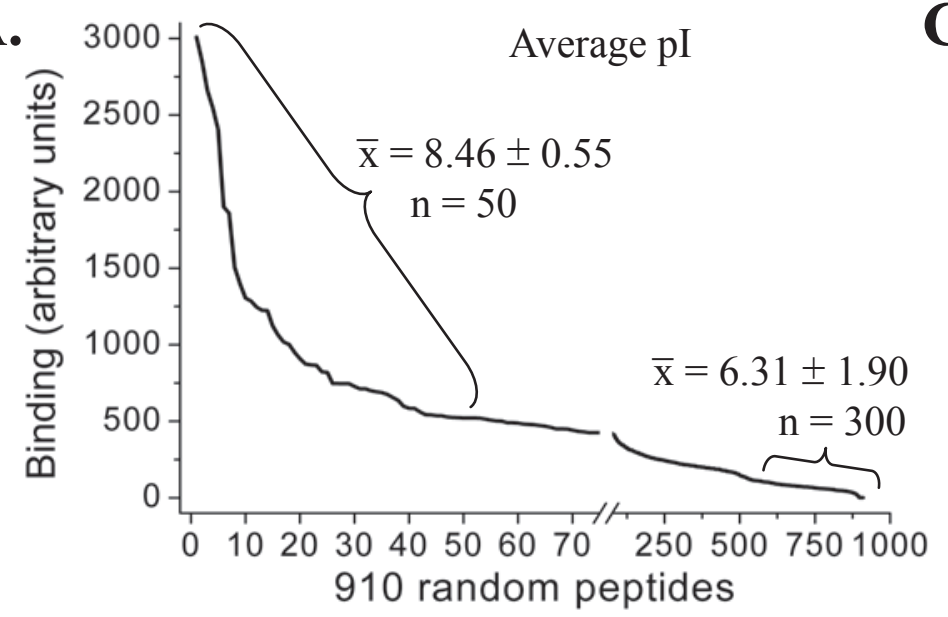

B.
C. PROTEIN

PEPTIDE

VALUE

Known interactions

RF-C KGKQVTLFDFIKK 2608

Fen1 AGKQSTLESWFIK 1260

PolB KTKQVGLGAWLKF 384

DNA ligase QLYQKLEKTTMKL 151

Predicted PCNA interacting motifs

RnaseHII KRAQLTLDNFLKR 2578

PAB2263 RSKQKTLDFFTP- 1884

Negative control peptides

QLNQITIMSFLGV 39

RRGQISIEFLFLI 13

LKAQISIDFLIAL ND

NFEVTTIILLFIL 16

RSLVASLIIFILI 15

SLGVRSLALFLRI 11

TTGVKGLDELLGG ND

NKRVLGIISLLVL ND

TTGVKGLDELLGG ND

KEVKEEYKRFLEE ND

NCVLDKKFKDCL 
A.
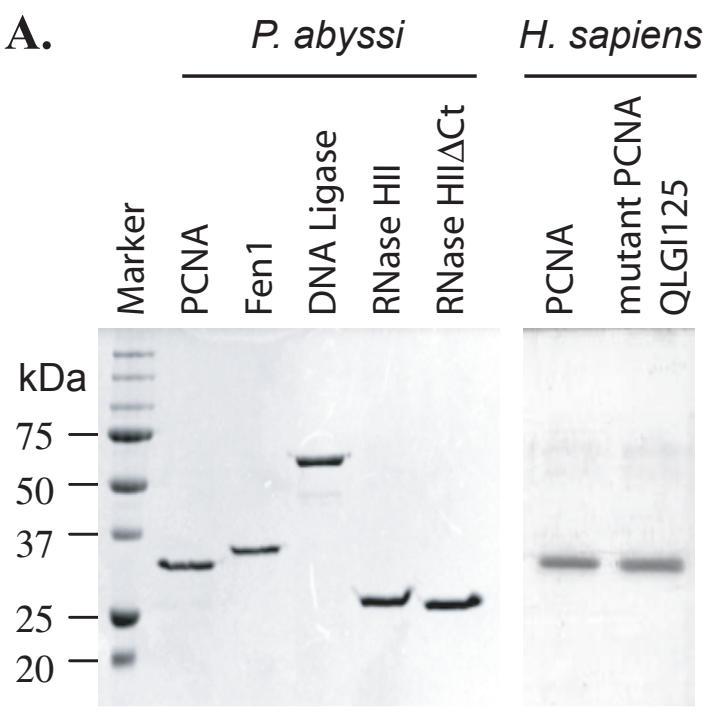

C.

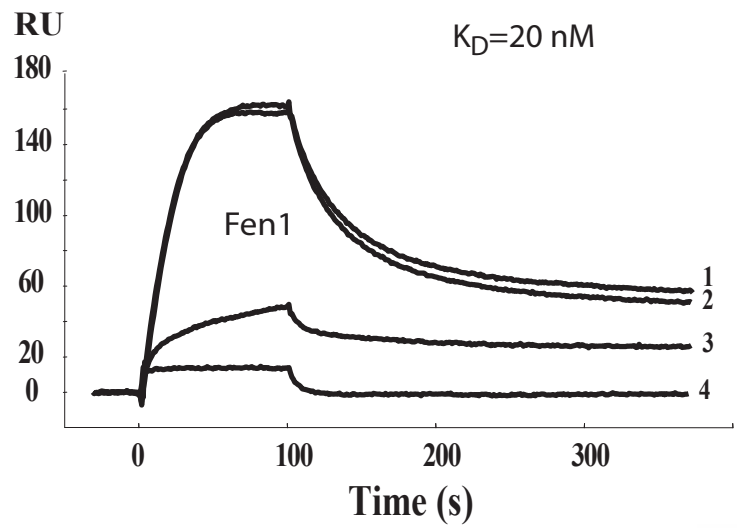

E.

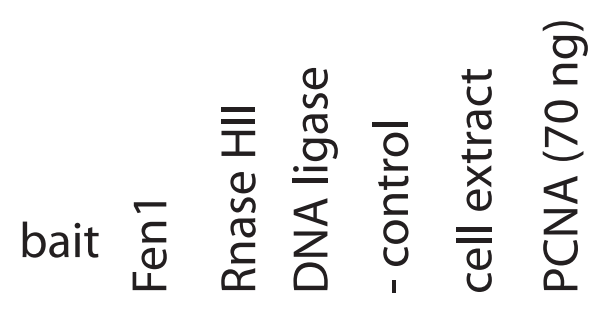

B.

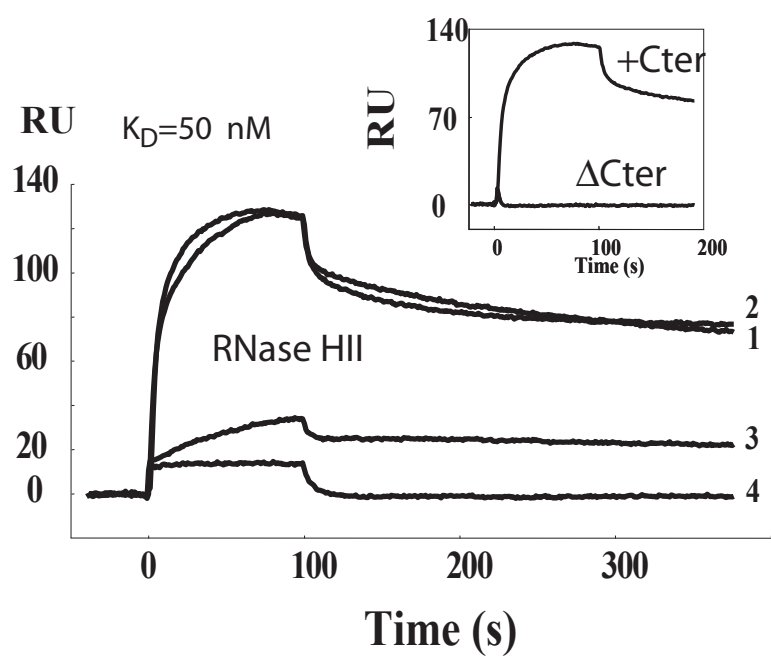

D.

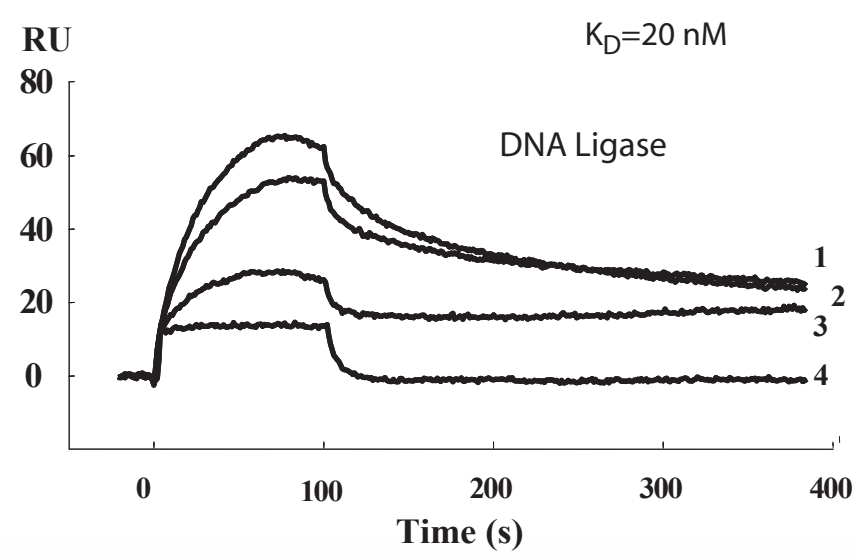

F.

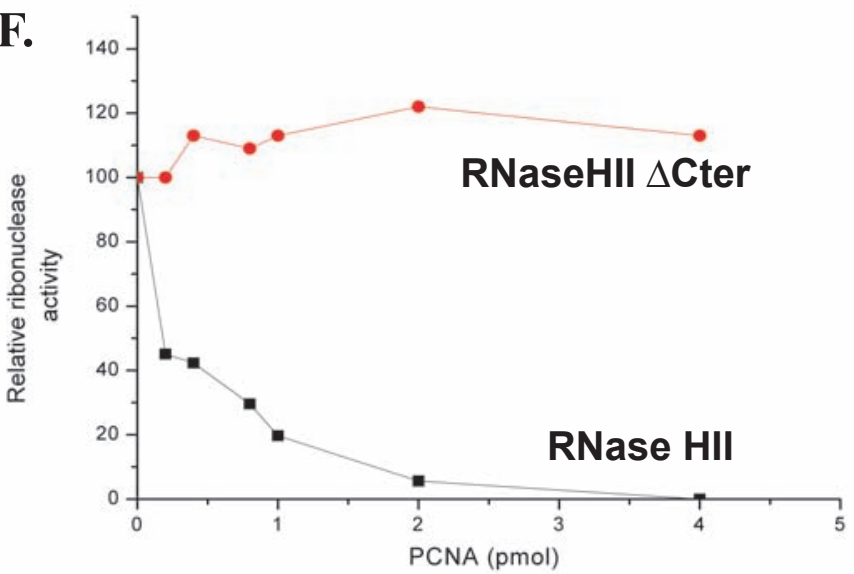


A Wild type

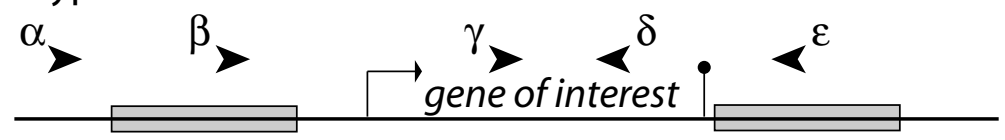

Deletion mutant

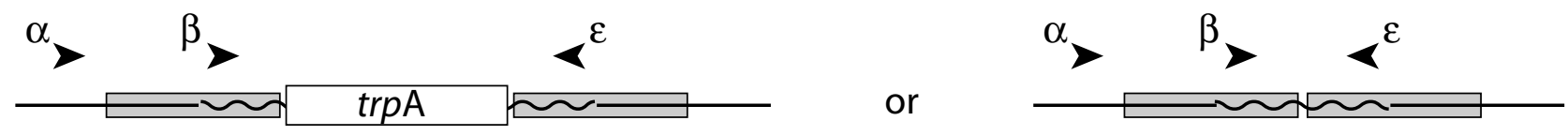

B

\begin{tabular}{|c|c|c|c|c|c|c|c|c|c|c|}
\hline \multicolumn{3}{|c|}{ Strain } & H53 & CN7 & CN8 & CN9 & CNY10 & CNY11 & CN16 & CN17 \\
\hline \multicolumn{3}{|c|}{ Genotype } & \multirow{2}{*}{$\begin{array}{c}\text { pHV2- } \\
\text { ApyrE2 } \\
\Delta \operatorname{trpA}\end{array}$} & \multirow{2}{*}{$\begin{array}{c}\mathrm{H} 53 \\
\Delta r n h B\end{array}$} & \multirow{2}{*}{$\begin{array}{c}\mathrm{H} 53 \\
\Delta f e n 1\end{array}$} & \multirow{2}{*}{$\begin{array}{l}\mathrm{H} 53 \Delta \text { fen1 } \\
\Delta r n h B:: \operatorname{trp} A\end{array}$} & \multirow{2}{*}{$\begin{array}{c}\mathrm{H} 53 \\
\Delta r n h A:: \operatorname{trp} A\end{array}$} & \multirow{2}{*}{$\begin{array}{l}\mathrm{H} 53 \Delta r n h B \\
\Delta r n h A:: \operatorname{trp} A\end{array}$} & \multirow{2}{*}{$\begin{array}{c}\mathrm{H} 53 \Delta \text { fen1 } \\
\Delta r n h A:: \operatorname{trpA}\end{array}$} & \multirow{2}{*}{$\begin{array}{c}\mathrm{H} 53 \Delta \text { fen } 1 \\
\Delta r n h B \\
\Delta r n h A:: \operatorname{trp} A\end{array}$} \\
\hline Gene & Oligonucleotides & position & & & & & & & & \\
\hline \multirow{3}{*}{ fen 1} & OCN72 - OCN92 & $\alpha-\varepsilon$ & 1792 & & 782 & 782 & & & 782 & 782 \\
\hline & OCN93 - OCN92 & $\beta-\varepsilon$ & 1114 & & 104 & 104 & & & 104 & 104 \\
\hline & OCN144-OCN145 & $\gamma-\delta$ & 529 & & 0 & 0 & & & 0 & 0 \\
\hline \multirow{3}{*}{$\operatorname{rnh} A$} & YGH32 - YGH34 & $\alpha-\varepsilon$ & 1387 & & & & 1555 & 1555 & 1555 & 1555 \\
\hline & YGH33 - YGH34 & $\beta-\varepsilon$ & 900 & & & & 1068 & 1068 & 1068 & 1068 \\
\hline & OCN150-OCN151 & $\gamma-\delta$ & 443 & & & & 0 & 0 & 0 & 0 \\
\hline \multirow{3}{*}{$\operatorname{rnh} B$} & OCN74 - OCN95 & $\alpha-\varepsilon$ & 1335 & 693 & & 1658 & & 693 & & 693 \\
\hline & OCN94 - OCN95 & $\beta-\varepsilon$ & 758 & 116 & & 1081 & & 116 & & 116 \\
\hline & OCN152-OCN153 & $\gamma-\delta$ & 333 & 0 & & 0 & & 0 & & 0 \\
\hline
\end{tabular}

C fen 1

$r n h A$

$r n h B$

locus

$\alpha-\varepsilon \quad \beta-\varepsilon \quad \gamma-\delta$

$\alpha-\varepsilon \quad \beta-\varepsilon \quad \gamma-\delta$

$\alpha-\varepsilon \quad \beta-\varepsilon$

primers

$\begin{array}{llllll}\mathrm{H} 53 & \mathrm{CN} 17 & \mathrm{H} 53 & \mathrm{CN} 17 & \mathrm{H} 53 & \mathrm{CN} 17\end{array}$ $\begin{array}{llllll}\mathrm{H} 53 & \mathrm{CN} 17 & \mathrm{H} 53 & \mathrm{CN} 17 & \mathrm{H} 53 & \mathrm{CN} 17\end{array}$
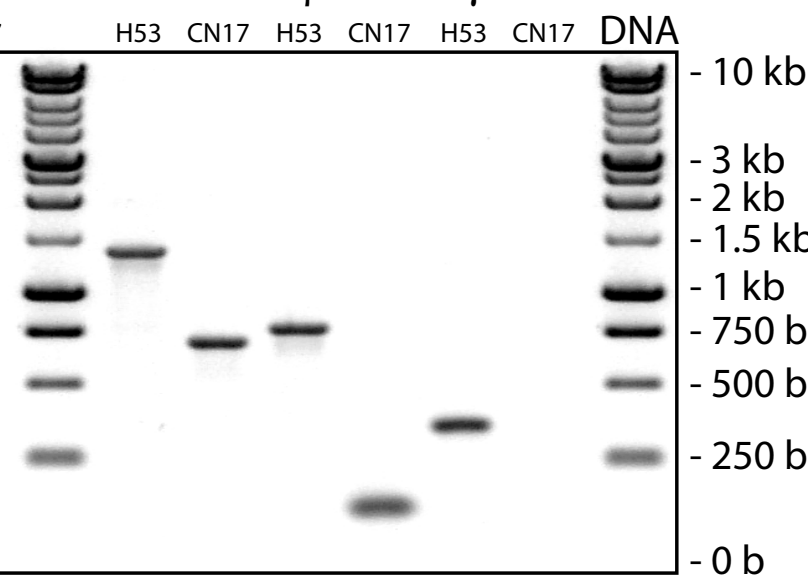

D

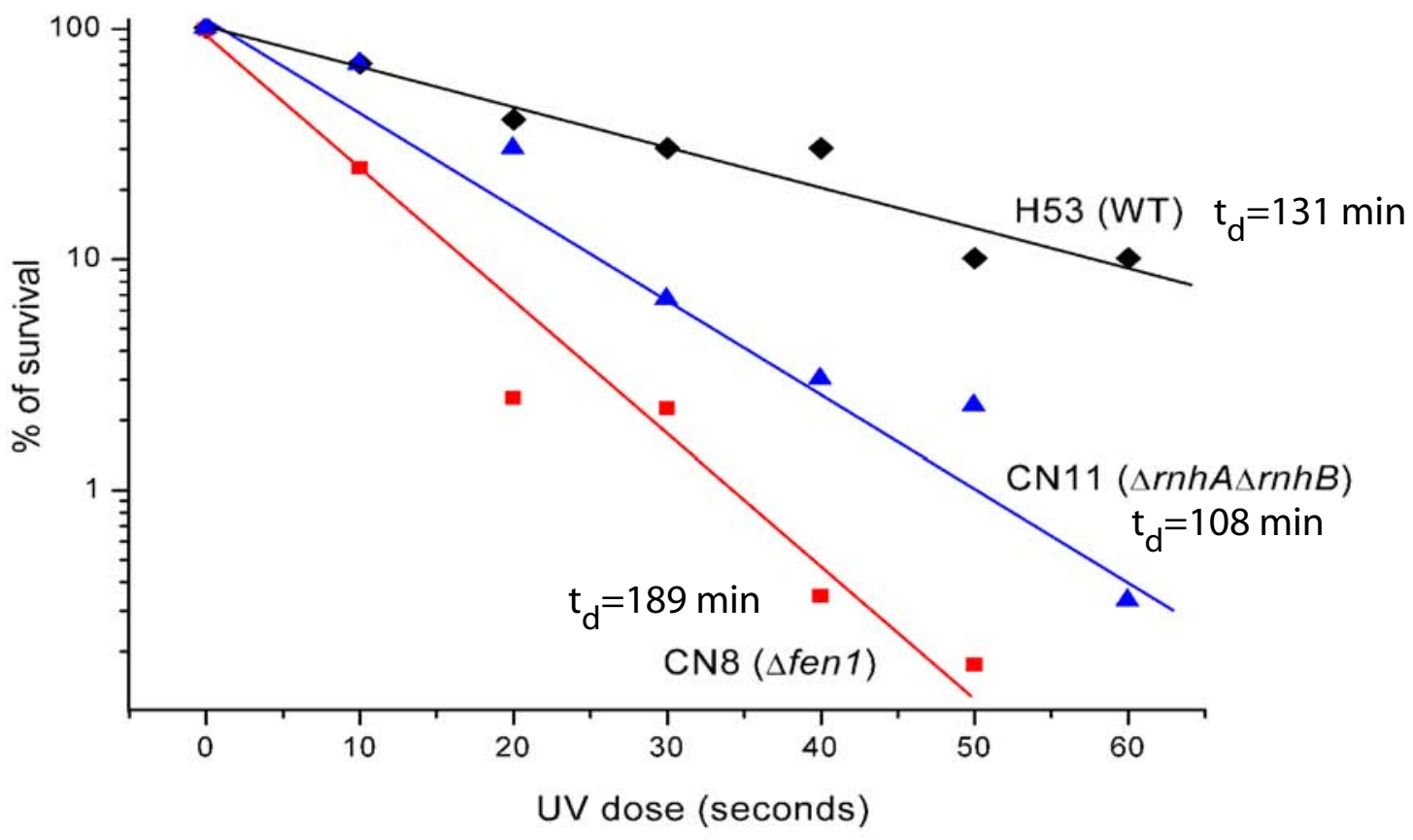


A.

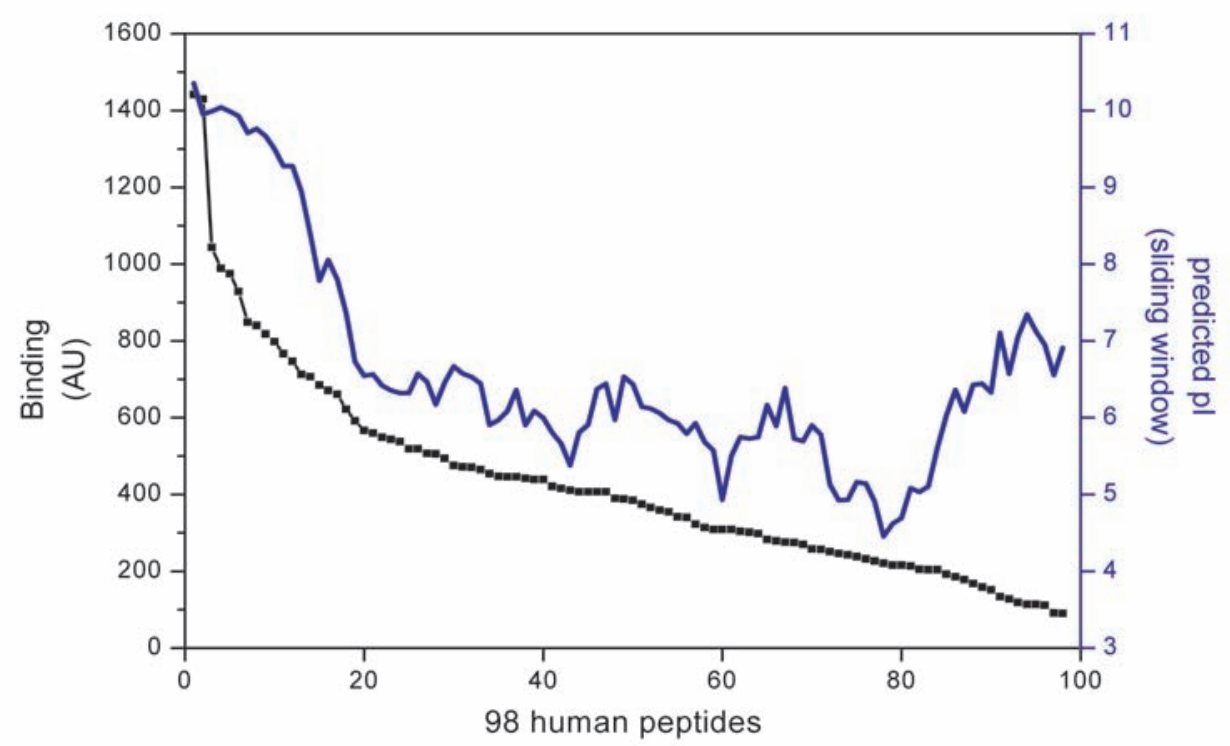

B.

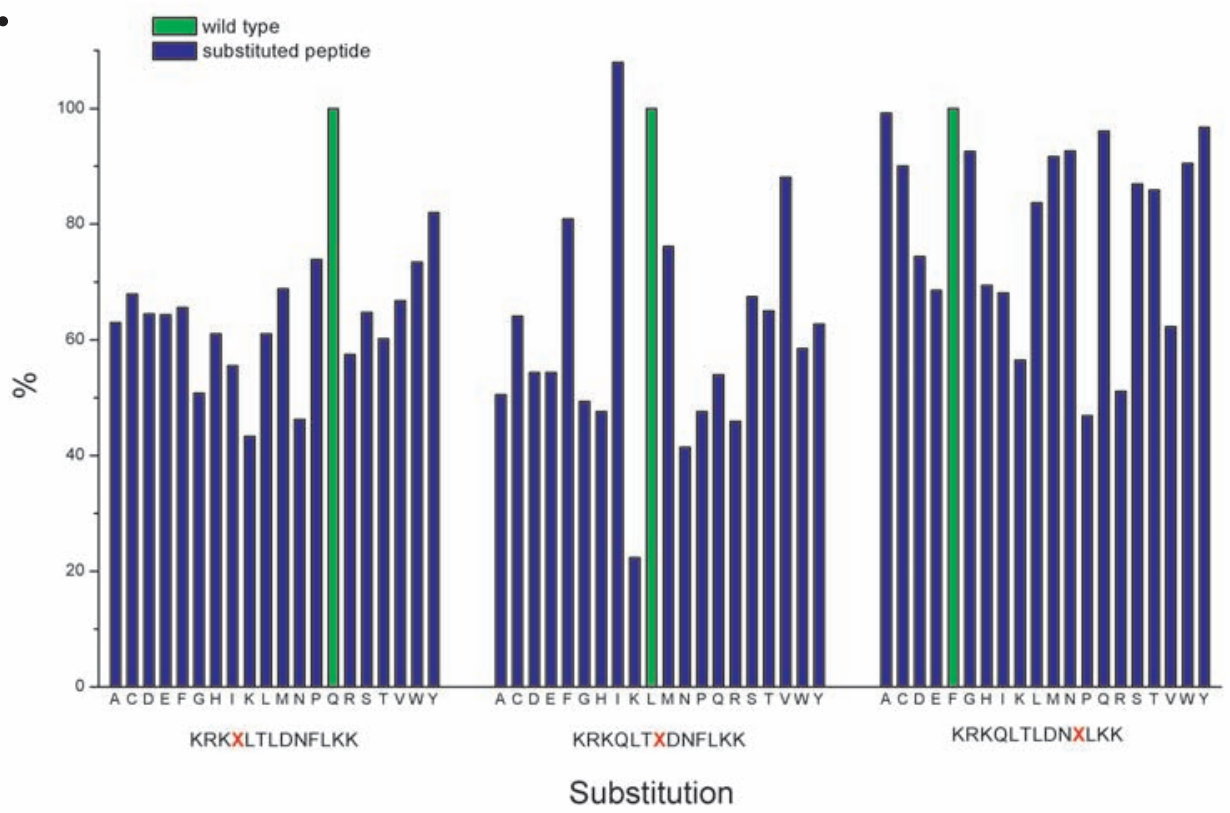

C.

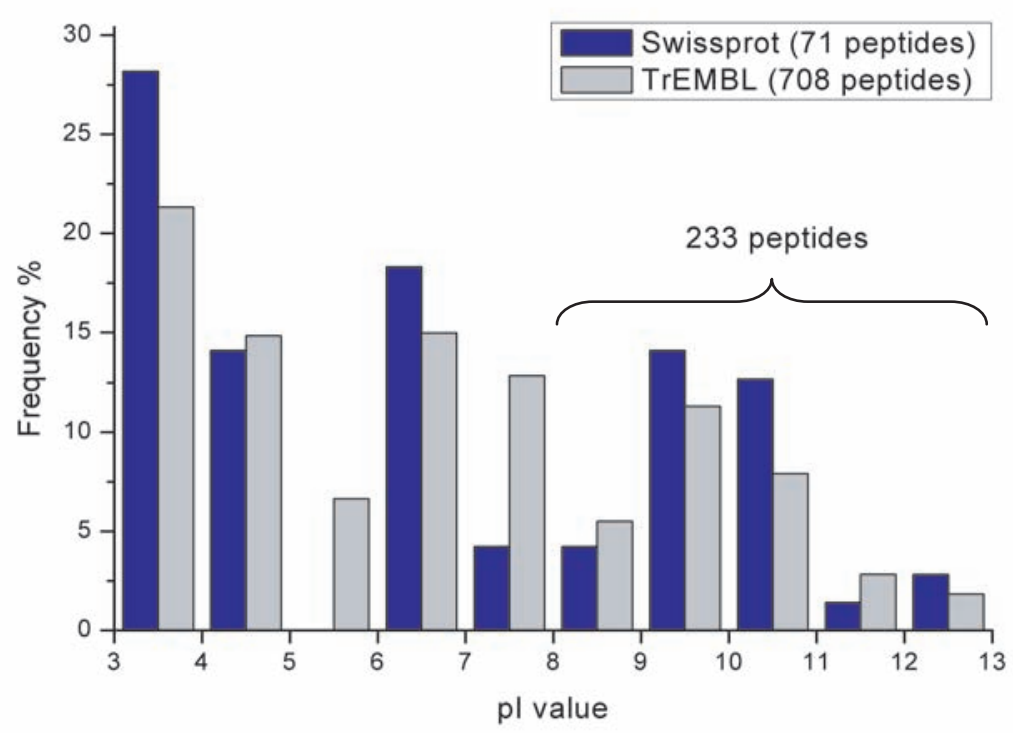




\section{Table S1}

Random peptides with the binding values higher than 500. The alignment of the peptides shown in the bold type is shown in Figure $1 \mathrm{~B}$.

\begin{tabular}{|c|c|}
\hline Peptide sequence & Binding value \\
\hline FCQFKYMKMSCA & 3008 \\
\hline VCNRVGPIRKCD & 2854 \\
\hline QCKFFKDIGKCD & 2660 \\
\hline KCMKQSQNLQCW & 2549 \\
\hline RCWQKMMGVRCD & 2404 \\
\hline YCNGGQTKFTCR & 1900 \\
\hline VCKVIQDGKGCF & 1858 \\
\hline SCPGATKHLSCY & 1507 \\
\hline QCQFQMPTRWCY & 1397 \\
\hline YCQTWNSDRTCK & 1305 \\
\hline QCKTYEPLQRCG & 1285 \\
\hline MCKEVRISKDCA & 1246 \\
\hline FCTKMGSIQACA & 1225 \\
\hline RCQYKENIRPCL & 1223 \\
\hline NCVLDKKFKDCL & 1122 \\
\hline LCGAKKKTESCN & 1062 \\
\hline MCYKSNGGRMCI & 1018 \\
\hline RCQGTSSPGNCR & 1002 \\
\hline SCRMLQHLMACY & 950 \\
\hline QCSPKFVQASCH & 908 \\
\hline QCRFMAQLRSCV & 874 \\
\hline RCARKTAEAMCT & 868 \\
\hline KCMQRHAWVKCE & 865 \\
\hline LCWKNKILEMCS & 823 \\
\hline ICTKKMHIMLCD & 819 \\
\hline KCSNSLNQFDCL & 747 \\
\hline WCQTMWDKQRCV & 747 \\
\hline VCLRDITKMACM & 746 \\
\hline RCDKQTAPWTCM & 746 \\
\hline TCNQYQRILRCG & 727 \\
\hline WCKSINNMRICA & 712 \\
\hline WCTPPNKFTHCL & 712 \\
\hline RCIRWKANSDCM & 699 \\
\hline SCHKWENVIRCR & 693 \\
\hline LCRAAQAIPRCV & 687 \\
\hline GCASLRHGGQCS & 676 \\
\hline RCPPSSFRMSCV & 656 \\
\hline KCPWKAEHRQCV & 637 \\
\hline DCMLGLAYRPCK & 598 \\
\hline KCFHKEFVGYCR & 585 \\
\hline RCDMGTRAHTCH & 584 \\
\hline QCPAMMFYPNCK & 561 \\
\hline QCQVHKRYTGCG & 543 \\
\hline YCLQSALNIKCS & 542 \\
\hline PCKFYREKHICD & 537 \\
\hline KCRGTMDHDFCK & 536 \\
\hline
\end{tabular}




\section{Figure S1A}

The list of peptides with the motif Q-x(4,5)-[HFD][FY] showing top a binding signal higher than 400 is shown. Known interaction partners of the human PCNA are indicated in the bold.

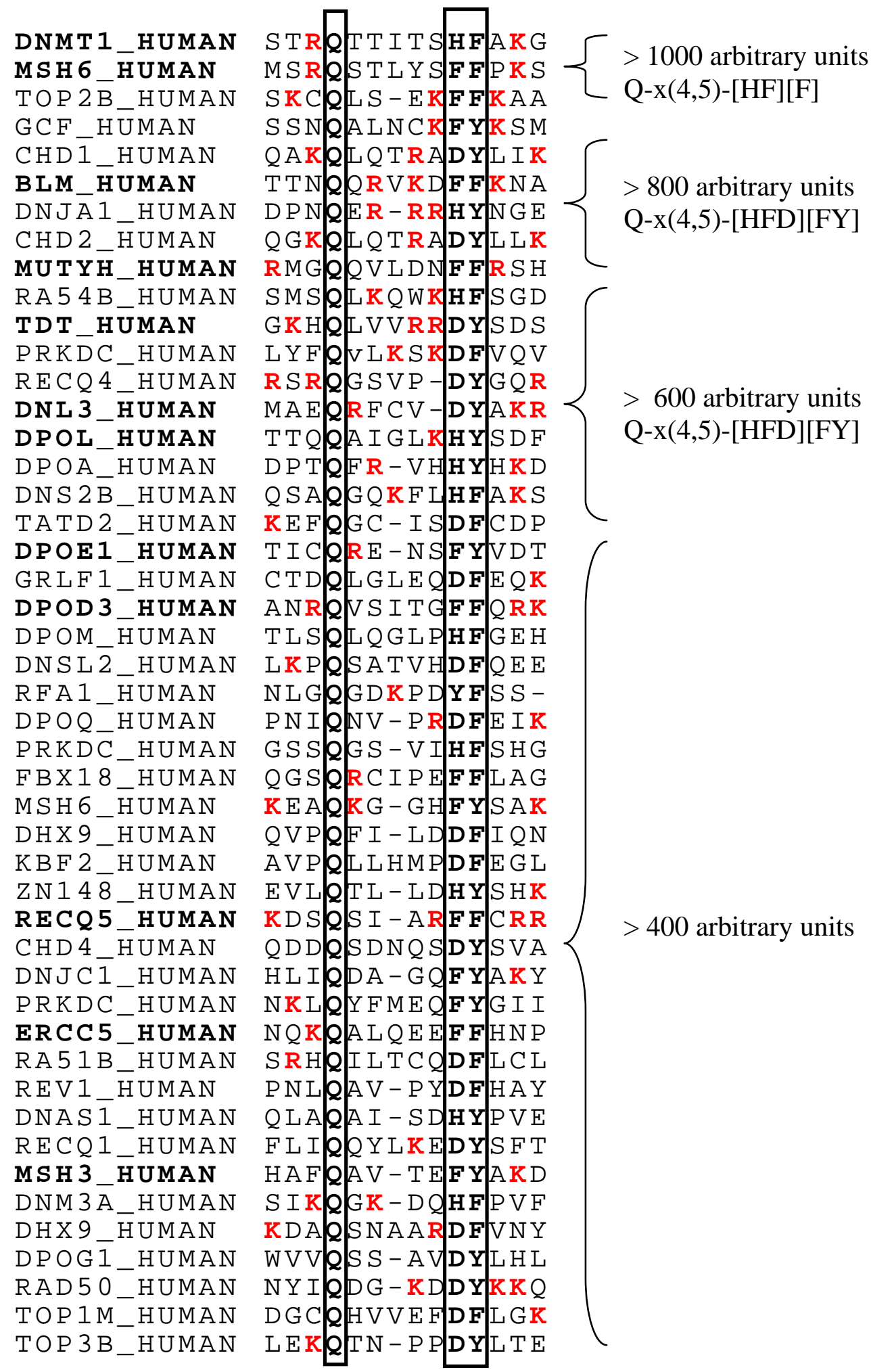




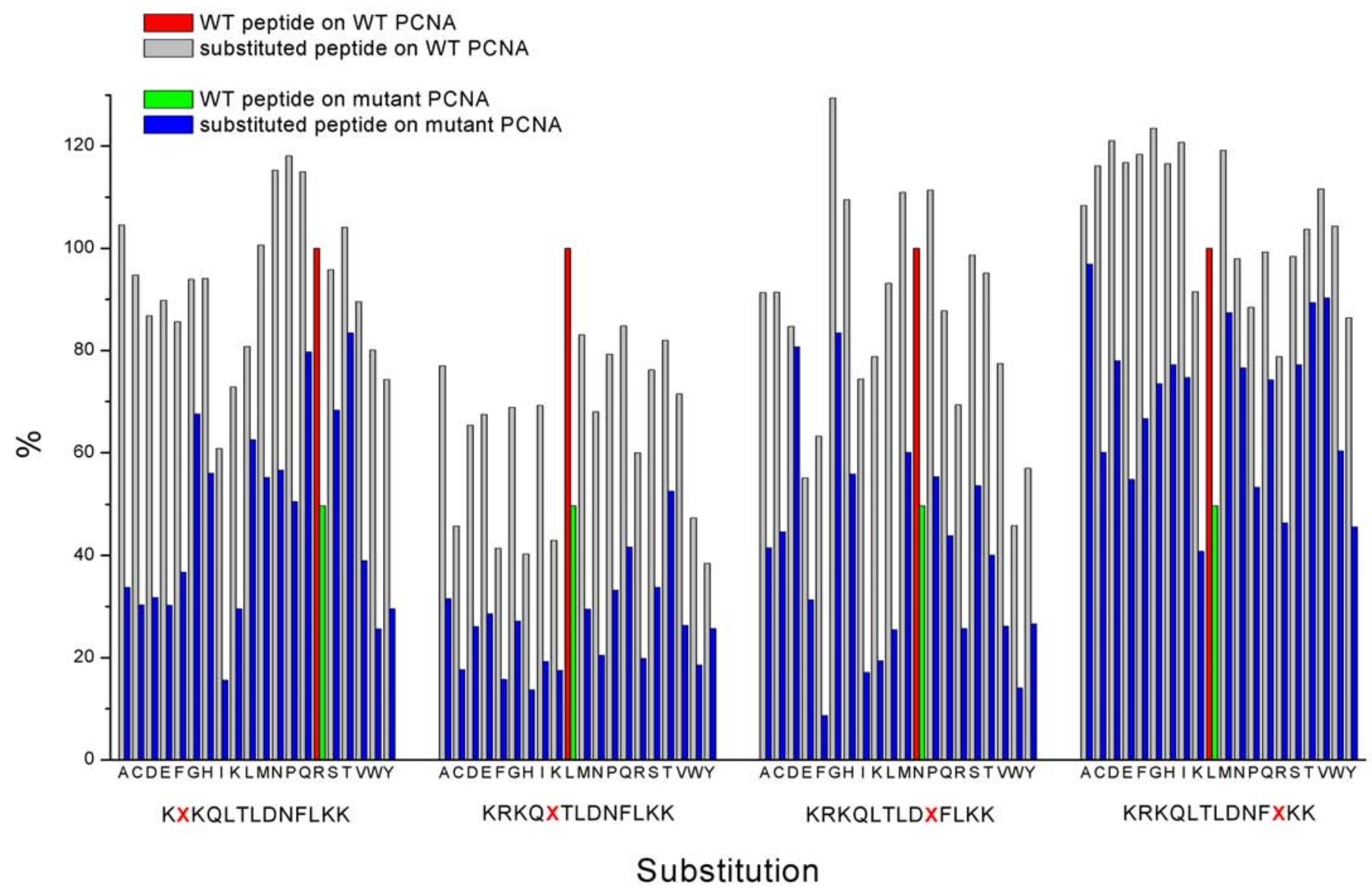





